\title{
Phylogenetic relationships and status of taxa of Pulsatilla uralensis and $P$. patens s.str. (Ranunculaceae) in north-eastern European Russia
}

\author{
Olga E. Valuyskikh', Ludmila V. Teteryuk', Yana I. Pylina', \\ Oleg E. Sushentsov², Nikita A. Martynenko³, Dmitry M. Shadrin'
}

I Institute of Biology of Komi Scientific Center of Ural Branch of Russian Academy of Sciences, Kommunisticheskaya 28, Syktyvkar, 167982, Russia 2 Botanical Garden of Ural Branch of Russian Academy of Sciences, 8 Marta 202a, Yekaterinburg, 620144, Russia 3 K.A. Timiryazev Institute of Plant Physiology of Russian Academy of Sciences, Botanicheskaya 35, Moscow, 127276, Russia

Corresponding author: Olga E. Valuyskikh (valuyskikh@ib.komisc.ru)

Academic editor: Marco Pellegrini | Received 17 April 2020 | Accepted 25 August 2020 | Published 9 October 2020

Citation: Valuyskikh OE, Teteryuk LV, Pylina YI, Sushentsov OE, Martynenko NA, Shadrin DM (2020) Phylogenetic relationships and status of taxa of Pulsatilla uralensis and P. patens s.str. (Ranunculaceae) in north-eastern European Russia. PhytoKeys 162: 113-130. https://doi.org/10.3897/phytokeys.162.53361

\begin{abstract}
We studied the allopatric complex Pulsatilla patens (L.) Mill. s.lat. (Ranunculaceae) in north-eastern European Russia and the Urals. In this region, there are two kinds of P. patens with different perianth colours in monochrome and polychrome populations. To clarify their taxonomic boundaries, we used the sequences of chloroplast DNA ( $r b c \mathrm{~L}$ and $m a t \mathrm{~K})$ and nuclear DNA (ITS2), in addition to morphological characteristics. The combination of three markers $(r b c \mathrm{~L}+m a t \mathrm{~K}+\mathrm{ITS} 2)$ was found to be the most effective for phylogenetic resolution. The samples of two morphologically-different taxa $P$. uralensis and $P$. patents s.str. were shown to form a single clade on the phylogenetic tree. Based on the molecular phylogenetic analysis, we were not able to unequivocally prove the independent existence of $P$. uralensis.
\end{abstract}

\section{Keywords}

DNA barcode, molecular phylogeny, taxonomy, Ranunculales, ITS2, rbcL, matK

Copyright Olga E. Valuyskikh et al.. This is an open access article distributed under the terms of the Creative Commons Attribution License (CC BY 4.0), which permits unrestricted use, distribution, and reproduction in any medium, provided the original author and source are credited. 


\section{Introduction}

The genus Pulsatilla Mill., which is sometimes included in Anemone s.lat. (e.g. Hoot et al. 1994, 2012), comprises more than 30 taxa which, as a rule, form intricate species complexes with a high degree of morphological variability (Stepanov 2014; Li et al. 2019; Sramko et al. 2019). The general classification, boundaries and the number of species and lower taxa have been revised several times, but no consensus has yet been reached (e.g. Tamura 1995; Tzvelev 2012; Grey-Wilson 2014). Furthermore, taxa of Pulsatilla often hybridise with each other in common habitats (Akeroyd 1993; Bakin 2005; Stepanov 2014), which makes it difficult to define the species' boundaries. Many species and subspecies of Pulsatilla are rare and subject to protection (Holub and Prochazka 2000; Council of the European Union 2007; Bardunov and Novikov 2008; The IUCN Red List of Threatened Species 2019). In the Russian Federation, even widespread Pulsatilla species are subject to protection due to the small number of habitats, small population sizes and high anthropogenic impact. Fourteen species of Pulsatilla are recorded in the European part of Russia (Tzvelev 2001) and 11-15 in the Asian part (Malyshev 2012; Timokhina 1993). In addition, there are several questions regarding the identification and size of taxa within the $P$. patens s.lat. complex, despite several recent studies on molecular phylogenetic relationships in the genus ( $\mathrm{Li}$ et al. 2019; Sramko et al. 2019).

In the Urals and the adjacent parts of the Russian Plain, four taxa of Pulsatilla ser. Patentes can be found: P. patens s.str., P. uralensis (Zamelis) Tzvelev, P. multifida (Pritz.) Juz. and $P$. angustifolia Turcz. (Tzvelev 2001, 2012). The main diagnostic characteristics used to recognise taxa within $P$. patens s.lat. are the colour of the perianth, the degree of dissection of the leaf blade (i.e. number of teeth), the presence and length of the petiolule of the apical segment and the width of the apical segment (Juzepczuk 1937; Tzvelev 2001; Egorova et al. 2017). All of them have extensive ranges of distribution and different centres of speciation, but only $P$. patens s.str. and $P$. uralensis are found in the Komi Republic. The European P. patens s.str. (= P. patens subsp. patens) only slightly expands beyond the boundaries of Europe. It is mainly distributed on the western macro-slope of the Urals (Central and Southern Urals) and also extends into Siberia and Central Asia (Tzvelev 2001; Sushentsov 2008). In Europe, this taxon is morphologically fairly uniform, but becomes extremely polymorphic in the Urals and Siberia (Juzepczuk 1937). Pulsatilla uralensis is distributed in the Central and Southern Urals (Kulikov 2005; Sushentsov 2008) and the adjacent part of the Russian Plain, in the basin of the Vyatka River (Egorova et al. 2017).

Due to the past separate geographical range, which suggests allopatric geographic isolation, and nomenclature confusion the circumscription of some species is a matter of much debate. For instance, $P$. uralensis (Zamelis) Tzvelev (= P. patens subsp. uralensis Zamelis) is often used synonymously with $P$. flavescens (Zucc.) Juz. [nom. illeg., nonBoros $=$ P. patens subsp. flavescens (Zucc.) Zamelis]. However, we consider these taxa to 
be conspecific and, despite the widespread use of both names in regional floristic surveys and databases (see The Plant List 2020; World Flora Online 2020; NCBI 2020), the name $P$. flavescens is illegitimate (Somlay 2000). Therefore, in this study, we will use the commonly-accepted name $P$. uralensis (Zamelis) Tzvelev (see Tzvelev 2001, 2012; The Euro+Med PlantBase 2020) in order to also avoid confusion with the homonym of the species.

To date, no particular research of Pulsatilla species in the allopatric zone in the northern part of European Russia (within $59^{\circ} 12^{\prime}-68^{\circ} 25^{\prime} \mathrm{N}$ and $45^{\circ} 25^{\prime}-66^{\circ} 15^{\prime} \mathrm{E}$ ) has been carried out. The northern boundary of the Pulsatilla range passes through the Komi Republic, while over 100 localities of plants of different coloured flowers are included under P. patens in the Red Book for the region (Martynenko 2009). The location of the region in the allopatric zone of European $P$. patens s.str. and Ural-Siberian $P$. uralensis, plus the elevated degree of polymorphism of diagnostic characteristics (i.e. colour of the perianth and dissection of the leaf blade) indicate the need to supplement the morphological methods with modern molecular genetic studies. Therefore, the aims of this work were to: 1) identify the taxa of $P$. patens s.lat. in north-eastern European Russia using herbarium specimens and wild populations; and 2) describe their phylogenetic relationships using plastid markers (matK and $r b c \mathrm{~L}$ ) and a nuclear marker (ITS2) recommended for plants by the DNA Barcode consortium.

\section{Materials and methods}

The study area is located in north-eastern European Russia (Fig. 1). Thirty-one samples from ten populations were collected by the authors from the Komi Republic, Orenburg Oblast and Sverdlovsk Oblast as detailed in Table 1. Most samples were collected from the Komi Republic within $59^{\circ} 12^{\prime}-68^{\circ} 25^{\prime} \mathrm{N}$ and $45^{\circ} 25^{\prime}-66^{\circ} 15^{\prime} \mathrm{E}$. In each population, generative specimens were collected during the flowering period, at least 5-15 m apart from each other. We collected: 1) nine samples from hybridogenous polychrome populations (i.e. I, II and III) with yellow or blue-violet flowers; 2) eleven samples of $P$. uralensis from monochrome populations (i.e. IV, V, VII, VIII and X) with yellow (from pale yellow to deep yellow) and occasionally with white flowers; and 3) nine samples of $P$. patens s.str. from monochrome populations (i.e. VI and IX) with blue-violet flowers (Table 1).

Furthermore, we analysed over 120 specimens of $P$. patens s.lat. from the Herbarium of the Institute of Biology of the Komi Scientific Center of the Ural Branch of the Russian Academy of Sciences (SYKO). According to morphological characteristics, these plants were identified as P. patens s.str. (Fig. 2) or P. uralensis (Fig. 3). Pulsatilla patens s.str. has blue-violet flowers, while $P$. uralensis has pale yellow to yellow flowers. The main morphological differences between $P$. patens s.str. and P. uralensis are summarised in Table 2. 


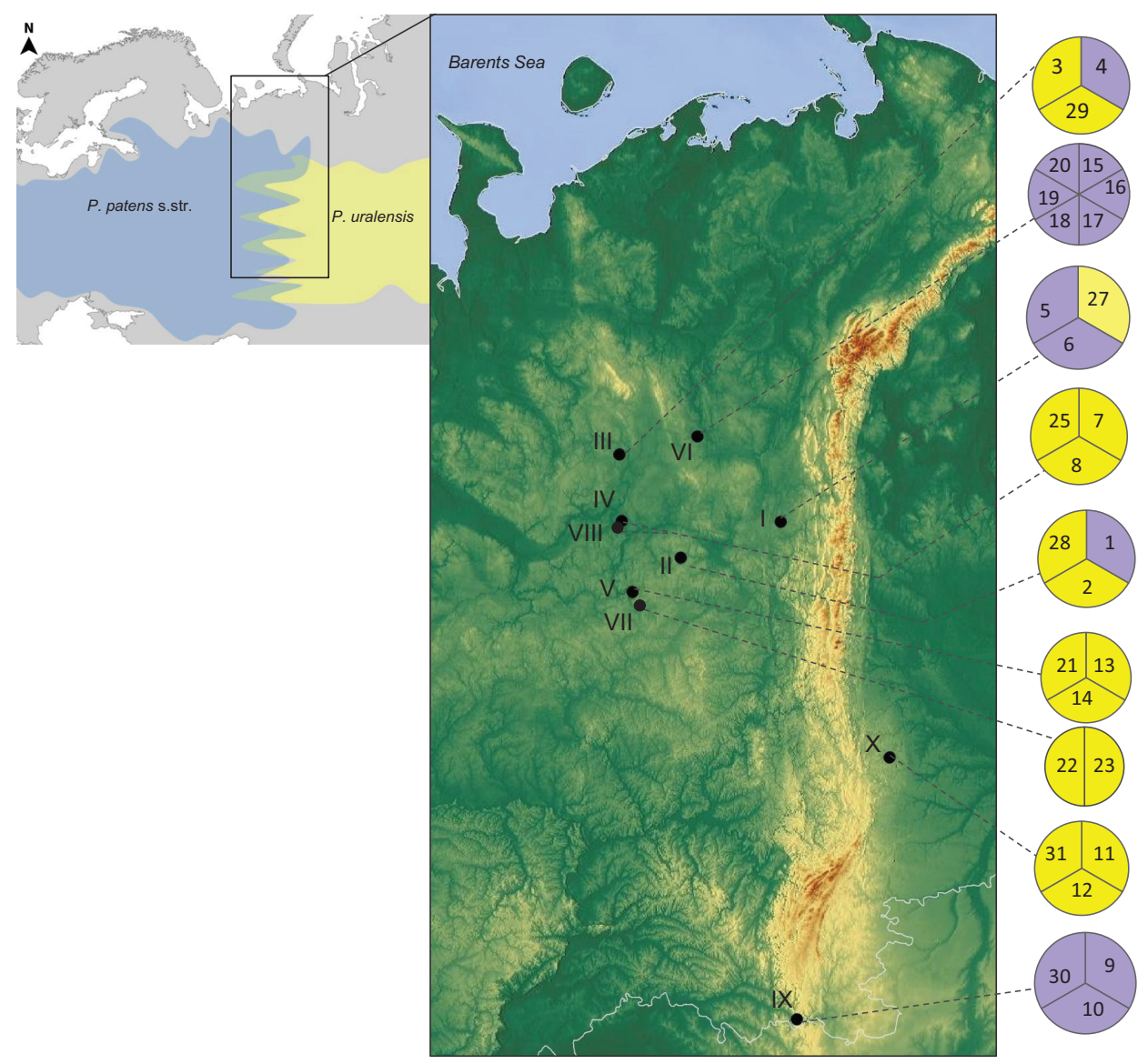

Figure I. Distribution map of the sampling sites of $P$. patens s.str. and $P$. uralensis in north-eastern European Russia and the Urals. The colour on the diagrams indicates the colour of the perianth in different taxa: blue-violet $-P$. patens s.str., yellow $-P$. uralensis. The locations (I-X) and samples correspond to Table 2.

\section{DNA extraction, amplification and sequencing}

Sequences of plastid DNA ( $r b c \mathrm{~L}$ and matK) and nuclear DNA (ITS2) have been successfully used for plant identification and DNA barcoding in various taxonomic groups (Cai et al. 2010, Wattoo et al. 2016, Saddhe Kumar 2017), including the genus Pulsatilla (Li et al. 2019). ITS2 is considered to be the most effective barcode for the identification of more than half of Pulsatilla species (Li et al. 2019). Therefore, we tested the ability of DNA barcoding to distinguish between the taxa of $P$. patens s.lat. Thirty-one samples were analysed and three barcode regions ( $r b c \mathrm{~L}$, matK and ITS2) were amplified, sequenced and aligned.

Total genomic DNA was isolated from dried leaves using the Sorb-GMO-B kit (Sintol, Russia) in accordance with the manufacturer's instructions. PCR fragments 
Phylogenetic relationships and status of the taxa of Pulsatilla patens s.lat.

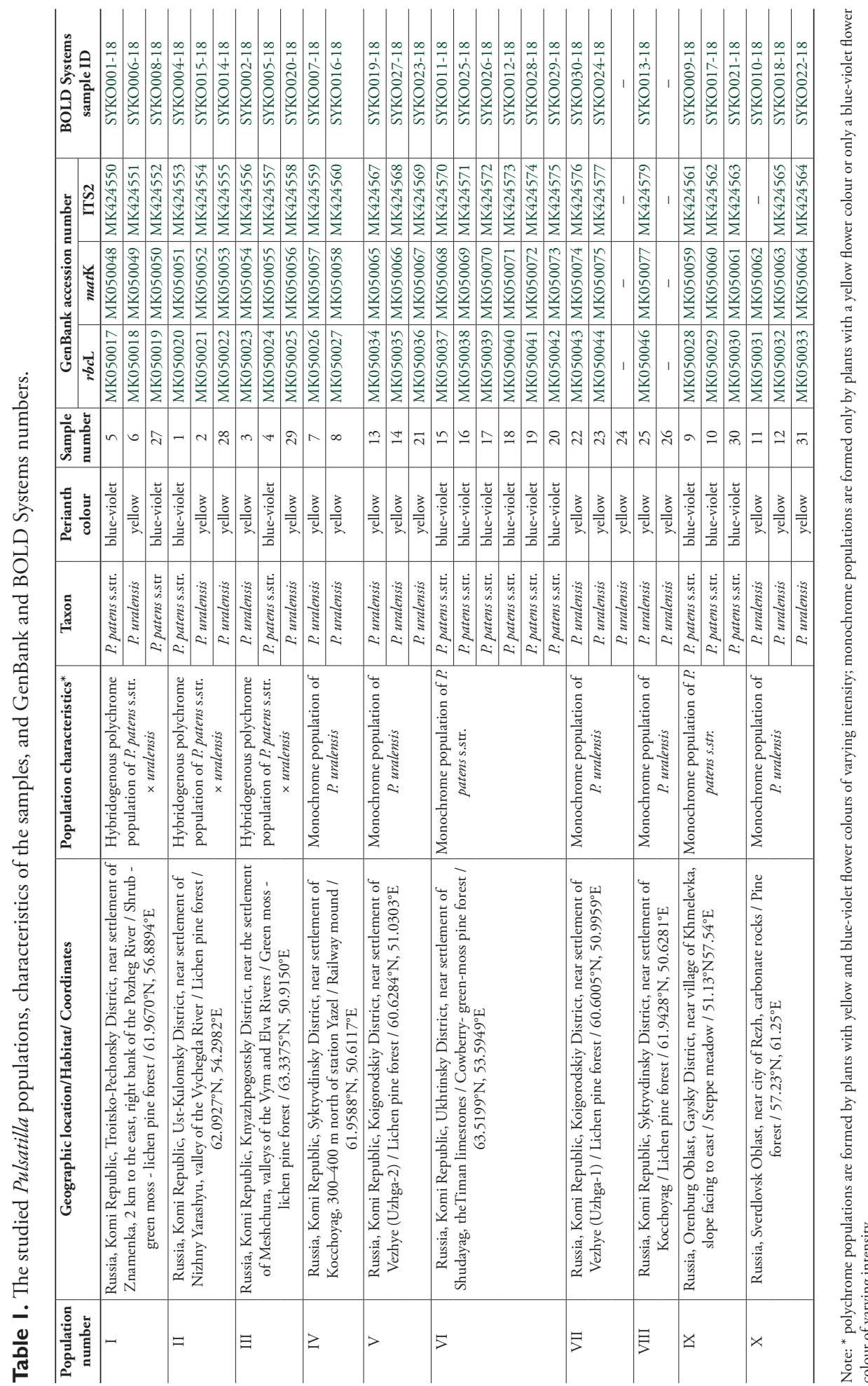


were amplified in $50 \mu \mathrm{l}$ of a mixture containing $10 \mu \mathrm{l}$ of Screen Mix (Eurogen, Russia), $10 \mu \mathrm{l}$ of each primer $(0.3 \mu \mathrm{M})$ (Eurogen, Russia), $18 \mu \mathrm{l}$ of $\mathrm{ddH}_{2} \mathrm{O}$ (Ambion, USA) and $2 \mu \mathrm{l}$ of DNA template $(1 \div 100 \mathrm{ng})$. The ITS2 sequences were amplified with universal primers ITS-5 (5'-GGAAGTAAAAGTCGTAACAAGG -3') and ITS-4 (5'-TCCTCCGCTTATTGATATGC- $3^{\prime}$ ); the $r b c \mathrm{~L}$ and matK sequences - with primers SI_For (5'- ATGTCACCACAAACAGAGACTAAAGC -3'), SI_Rev (5'-GTAAAATCAAGTCCACCRCG-3') and KIM 3F (5'-CGTACAGTACTTTTGTGTTTACGAG -3'), KIM 3R (5'-ACCCAGTCCATCTGGAAATCTTGGTTC-3'), respectively (Kress et al. 2009). Thermal cycling included heating to $95^{\circ} \mathrm{C}$ for $4 \mathrm{~min}$, followed by 34 cycles of 60 -s melting at $95^{\circ} \mathrm{C}, 30$-s annealing at $50{ }^{\circ} \mathrm{C}$ (for $r b c \mathrm{~L}$ ), $55^{\circ} \mathrm{C}$ (for ITS2), $61{ }^{\circ} \mathrm{C}$ (for $m a t \mathrm{~K}$ ) and 40 -s extension at $72^{\circ} \mathrm{C}$, with a final extension for $5 \mathrm{~min}$ at $72^{\circ} \mathrm{C}$. PCR and sequencing were carried out using the equipment of the Center for Collective Usage «Molecular Biology» of the Institute of Biology of the Komi Scientific Center of the Ural Branch of the Russian Academy of Sciences (Syktyvkar, Russia).

\section{Phylogenetic analysis}

Multiple alignments of nucleotide sequences were obtained using ClustalW in the MegaX programme (Thompson et al. 1994, Kumar et al. 2018). There were some missing data (see Table 2) and the alignments of the $r b c \mathrm{~L}$, matK loci and the ITS2 region were analysed separately and in concatenation $(r b c \mathrm{~L}+m a t \mathrm{~K}+\mathrm{ITS} 2)$.

Phylogenies were constructed based on the $G T R+\Gamma+I$ model for all alignments using the Bayesian Inference (BI) and Maximum Likelihood (ML) analysis. The BI analysis was conducted using MrBayes-3.2.5 (Ronquist and Huelsenbeck 2003). Three "hot" and one "cold" Markov chains were run for $1 \times 10^{6}$ cycles in two repetitions with the selection of each $200^{\text {th }}$ generated tree. The phylogenetic tree and the probabilities of its branching were obtained after discarding the first $25 \%$ of the model for estimating the parameters of nucleotide substitutions and their probabilities. The ML analysis was performed using the MegaX programme (Kumar et al. 2018) with bootstrap analysis from 1,000 replicas. Graphical viewing and editing of trees were carried out in the programmes Fig Tree (ver. 1.4.2) and Adobe Photoshop CC (19.0).

In the analysis, we used nucleotide sequences obtained by us or taken from the NCBI database (GenBank) and BOLD Systems (accessions numbers on phylogenetic trees are indicated in Table 2). Representatives of some species of Anemone, Anemoclema, Clematis and Hepatica were used as an external group. In this study, we discuss the phylogenetic hypotheses obtained from each individual dataset separately $(r b c \mathrm{~L}$, matK and ITS2) and analysis of the combined dataset of all three markers. All new $r b c \mathrm{~L}$, mat $\mathrm{K}$ and ITS2 sequences, obtained by us and used in this study, were deposited to the GenBank (accession No. MK050017-MK050077, MK424550-MK424579) and Barcode of Life databases (BOLD Systems sample ID: SYKO-PV-17508-SYKOPV-17536) (Table 2). Other Pulsatilla species from the BOLD Systems (BOLD Systems 2020) and GenBank (NCBI 2020) databases that had all three sequences ( $r b c \mathrm{~L}$, matK and ITS2) were used in phylogenetic analysis. 

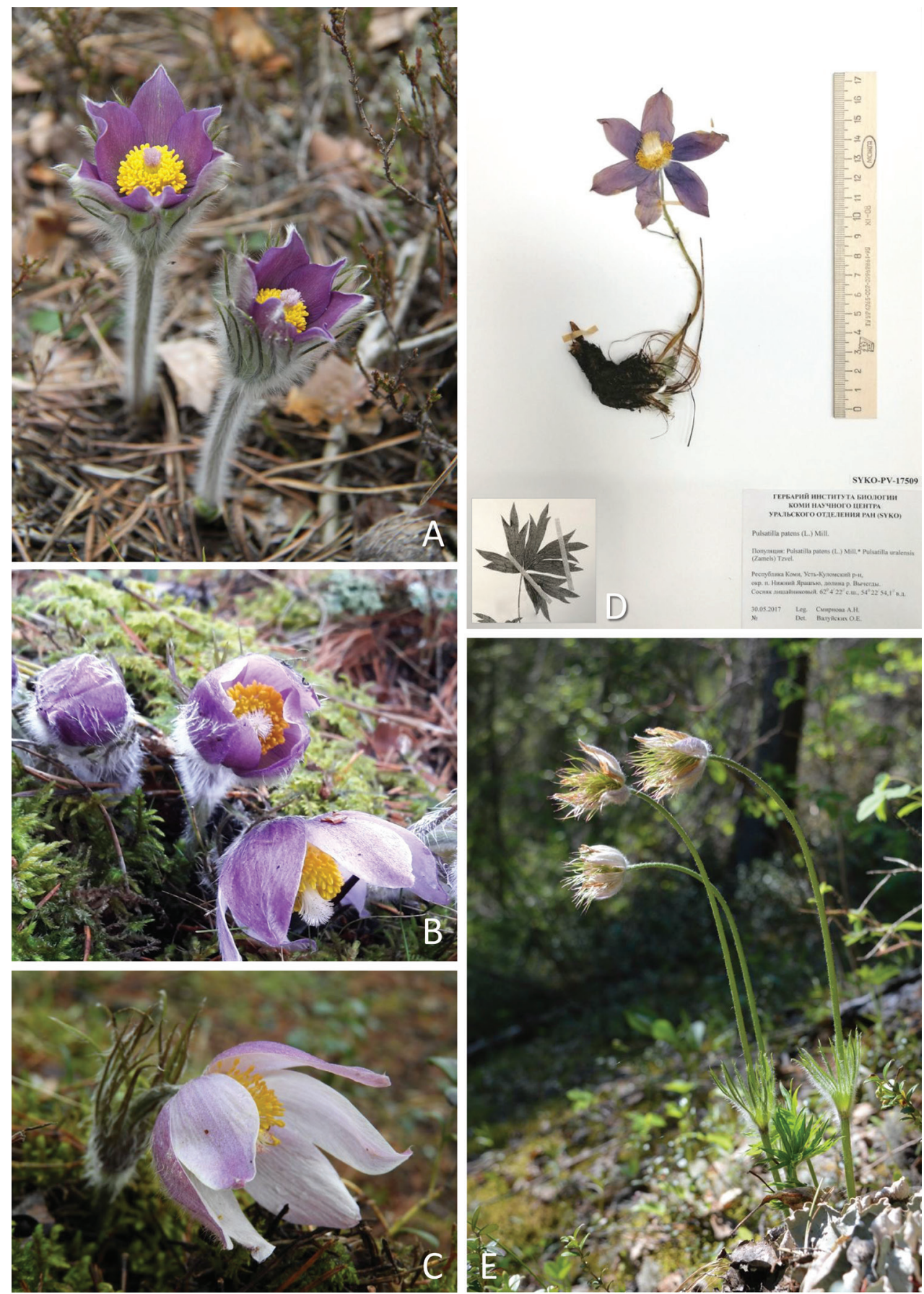

Figure 2. Pulsatilla patens s.str. (L.) Mill. (P. patens subsp. patens) A-C flowers with different perianth colour $\mathbf{D}$ herbarium specimen of a flowering shoot and typical leaf blade $\mathbf{E}$ plant just after flowering with unripe fruits. The photographs show sample number 5 (A, D), sample number 15 (B) and sample number $18(\mathbf{C})$. 

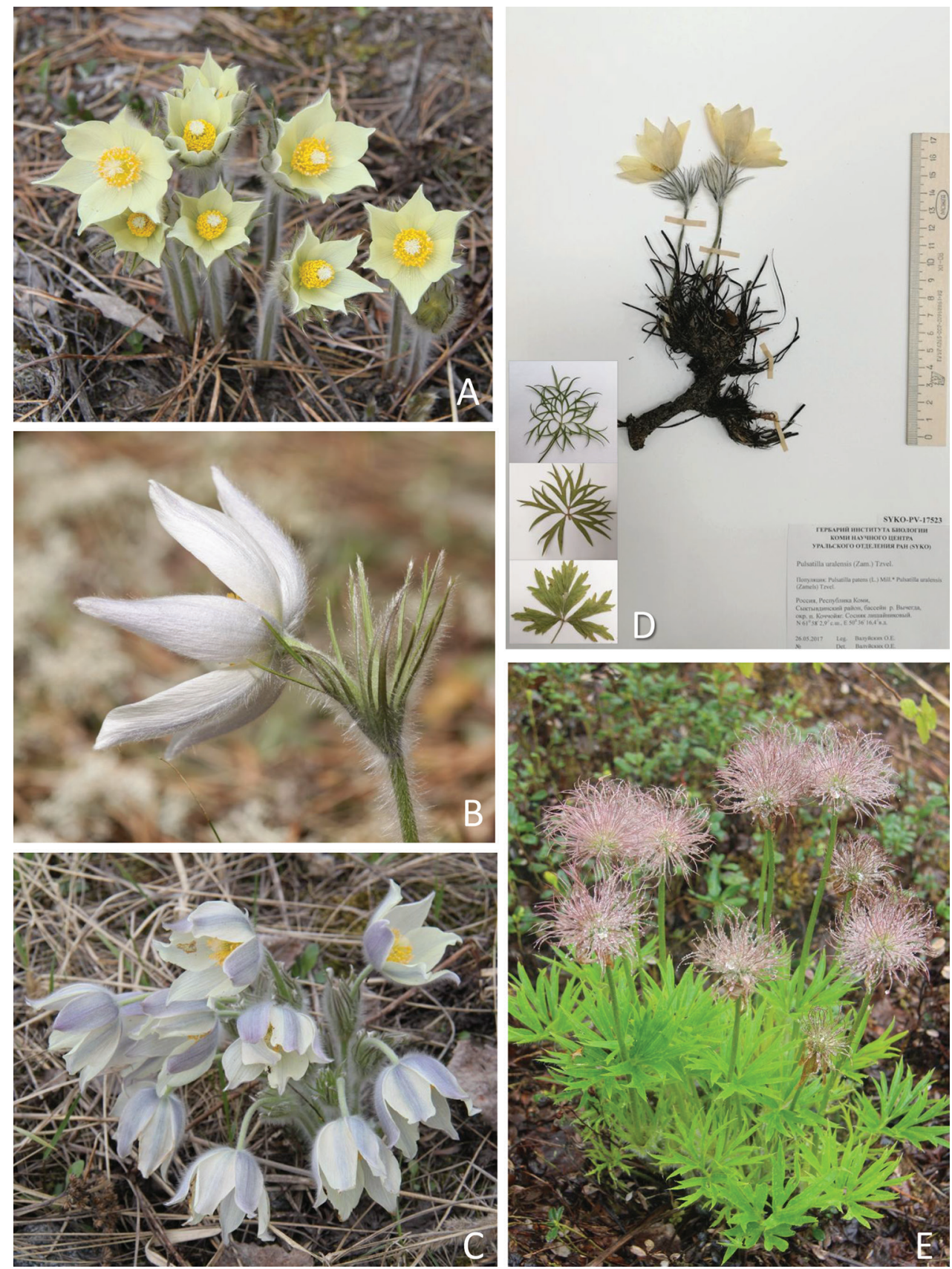

Figure 3. Pulsatilla uralensis (Zamelis) Tzvelev A-C flowers with different perianth colour $\mathbf{D}$ herbarium specimen of a flowering plant and different leaf blades $\mathbf{E}$ fruiting plant. The photographs show sample number 6 (B), sample number 7 (C) and sample number 25 (D). 
Table 2. Morphological comparison between P. patens s.str. and P. uralensis.

\begin{tabular}{lcc}
\hline \multicolumn{1}{c}{ Characters } & P. patens s.str. & P. uralensis \\
\hline Flower colour & Blue-violet (different saturation) & Yellow (white or light yellow) \\
Lobes of basal leaves & $\leq 26(17-30)$ & $\geq 26(22-43)$ \\
Width of leaf-lobes & $0.3-0.6 \mathrm{~cm}$ & $0.2-0.5 \mathrm{~cm}$ \\
Stalk of the central lobe of the basal & Absent & $0.7-1.2 \mathrm{~cm} /$ absent \\
leaves & & Early May to early June \\
Flowering time & Early May to early June & \\
\hline
\end{tabular}

\section{Results}

The data matrix of $r b c \mathrm{~L}$ sequences included $486 \mathrm{bp}, \operatorname{mat} \mathrm{K}-775 \mathrm{bp}$ and ITS2 - 214$215 \mathrm{bp}$. The concatenated data matrix of $r b c \mathrm{~L}+$ matK+ITS2 sequences included 1,476 bp.

We reconstructed molecular phylogenetic trees using BI and ML analyses and obtained similar topologies for concatenated dataset trees ( $r b c \mathrm{~L}$, matK and ITS2), including 37 terminals of Pulsatilla species and ten outgroups (Fig. 4). Pulsatilla alpina (subgenus Preonanthus) and P. kostyczewii (subgenus Kostyczewianae) were the first two splits within the genus Pulsatilla, respectively. All closely-related taxa from $P$. section Pulsatilla (P. patens s.str., P. uralensis, P. patens subsp. multifida, $P$. vernalis and $P$. vulgaris) and $P$. section Semicampanaria (P. turczaninovii, P. chinensis, $P$. cernua and $P$. dahurica) of the subgenus Pulsatilla belong to a clade with a high support (95\% BS and 1 PP). P. vulgaris and the section Semicampanaria belong to a clade with an elevated bootstrap value (78\% BS and 0.72 PP). Pulsatilla patens s.str. (samples No. 5, 15-20 and 30$)$ and $P$. vernalis belong to a clade with a low bootstrap value (56\% BS). We were not able to establish relationships for the remaining samples of $P$. patens s.str. (sample numbers 1, 4, 9, 10 and 27) and $P$. uralensis (sample No. 2, 3, 6, 7, 8, 12-14, 21-23, 25, 28, 29 and 31) from different geographic locations (Table 2), since they arose as terminals from a polytomy.

Trees that were constructed based on the sequences of single genes had a low resolution. On the phylogenetic tree of the plastid region $r b c \mathrm{~L}$, all species of the subgenus Pulsatilla were also united into one clade (see Suppl. material 1). The exceptions are the apical clade represented by two sequences of P. cernua and P. chinensis (63\% BS and $0.91 \mathrm{PP}$ ) and the subclade represented by eight sequences of $P$. patens s.str. (samples No. 5, 15-20 and 30) and P. vernalis (FBPL086-12) (65\% BS and 0.82 PP). The molecular analysis of the sequences showed that samples of $P$. patens s.str. (No. 5, 15-20 and 30) differ from the others by one variable site in the $r b c L$ region $\left(A / G_{61}\right)$ (see Suppl. material 2). Comparison of the matK and ITS2 sequences could not separate P. subgenera Pulsatilla, Kostyczewianae and Preonanthus (see Suppl. material 3, 4). On the $m a t K$ phylogenetic tree, the same clade is distinguished, including eight blue-flowered samples of $P$. patens s.str. (5 and 15-20), however, with low support (0.67 PP). For such samples, one variable site $\left(\mathrm{C} / \mathrm{T}_{472}\right)$ was identified (Suppl. material 2). 


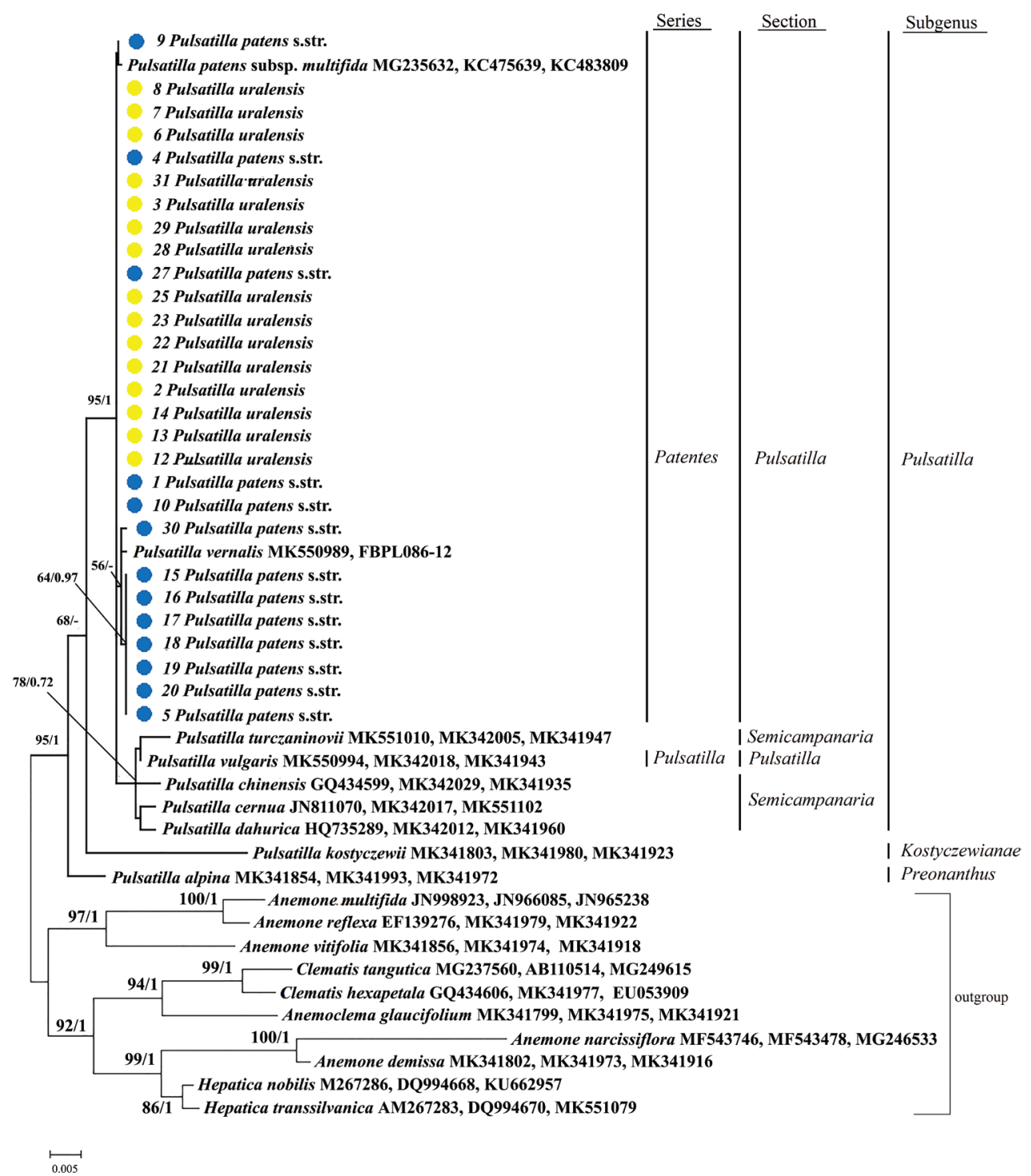

Figure 4. Combined Maximum Likelihood (ML) and Bayesian Inference (BI) phylogenetic tree $(r b c \mathrm{~L}+$ matK+ITS2) of 37 Pulsatilla samples and 10 outgroup samples. All new 28 samples of P. patens s.str. and P. uralensis are marked with dots. Outgroups include Anemone, Anemoclema, Clematis and Hepatica species. ML bootstrap support (left) and BI posterior probability (right) are recorded along branches. Values below $50 \%$ are not shown.

\section{Discussion}

Global climate perturbations throughout the Quaternary period caused active migrations of Pulsatilla within Eurasia, followed by secondary polyploidy and increased polymorphism (Sramko et al. 2019). The ancestor of the modern P. patens s.lat. popu- 
lations inhabiting north-eastern European Russia most likely grew in the steppes of Eastern Eurasia (Sramko et al. 2019). During the Pleistocene, the ancestor of the modern $P$. patens s.lat., perhaps, together with the southern Siberian forest-steppe species, spread to the west and further north along the Ural Mountains (Knyazev et al. 2007, Kulikov et al. 2013). Climate change associated with the Quaternary period contributed significantly to the diversification of $P$. patens s.lat. The disruption of the continuous distribution of species by the Pleistocene glaciations led to geographical disjunction and formation of a number of allopatric morphological forms in the European and Asian parts of the range of the species (Bobrov 1944; Tzvelev 2001; Ronikier et al. 2008; Kricsfalusy 2015 etc.). During the post-glacial colonisation, the ranges of migrants from several refugia started to touch or overlap in contact zones.

A part of the territory of north-eastern European Russia, including the Komi Republic, was covered by the last Late Pleistocene glaciations (Andreicheva 2002; Ilchukov 2010) and many of the known Pulsatilla locations in this region are the result of post-glacial colonisation. On the northern limit of the range, the most typical habitats for $P$. patens s.lat. are arid pine and mixed forests, forest clearings and edges. Large populations (up to 500-1,000 and more specimens) in the region are rare and are confined to lichen forests in the southern part of the Komi Republic $\left(60-62^{\circ} \mathrm{N}, 51-54^{\circ} \mathrm{E}\right)$. During the Pleistocene, climate changes led to repeated Meridional displacements of vegetation zones (Andreicheva 2002). Evidence of these processes is provided by the fragments of a relict petrophytic floristic complex that currently exists on limestones in the north-east of European Russia, including the Timan limestones (Yudin 1963; Teteryuk et al. 2006). Small and isolated populations of P. patens s.lat. (up to 150-200 specimens) survived at the outcroppings of bedrocks; they grow together with the species of the relict petrophytic floristic complex in the river valleys of the Timan limestones $\left(63-64^{\circ} \mathrm{N}, 52-53^{\circ} \mathrm{E}\right)$. Therefore, it is likely that some populations of $P$. patens s.str. (e.g. population VI), together with some species of bushes and herbaceous plants, survived during the last glaciations and are the part of more ancient vegetation compared to the adjacent flatland ecosystems that formed after the last ice-sheet glaciations.

Molecular phylogenetic analyses showed that all samples of $P$. patens s.str. and P. uralensis belong to a single clade and some groups within it arose with moderate statistical support, which makes it impossible to draw more definitive conclusions. Such low resolution is generally associated with Pulsatilla species (Li et al. 2019) and with specific factors related to the evolution of the species (by hybridisation and polyploidisation). Therefore, our discussion will be carefully constructed, given the low resolution that we obtained.

The obtained results of the molecular phylogenetic analysis (nuclear and chloroplast loci) are not consistent with the traditional morphological approach, according to which the isolation of $P$. patens s.str. and $P$. uralensis is based on the colour of the perianth - the distinctive feature on the level of species (Juzepczuk 1937; Tamura 1995; Tzvelev 2012; Egorova et al. 2017; amongst others). Only a small part of the samples belongs to a subclade (Fig. 4) that is represented exclusively by blue-flowered samples of P. patens s.str. (64\% BS and $0.97 \mathrm{PP})$. This small subclade includes only blue-flowered 
P. patens s.str. $(5,15-20)$ from the Komi Republic, P. patens s.str. (30) from the Orenburg Oblast of monochrome populations and European plant P. vernalis (MK550989, FBPL086-12). Such a relationship of the complex of $P$. patens s.lat. and $P$. vernalis with erect flowers and less dissected leaf blades was found by Sramko et al. (2019), who suggested to include $P$. vernalis into Series Patentes. Our phylogenetic trees showed that $P$. vernalis is close to $P$. patens s.str. (Fig. 4). These species are very different in morphology (e.g. $P$. vernalis has basal overwintering leathery leaves) and the range of $P$. vernalis does not currently cover north-eastern European Russia. It is an alpine species which, during the Ice Age in Europe, was widespread in the lowlands in sparse pine forests and heathlands. It is currently preserved in the Scandinavian refugia (Ronikier et al. 2008). Hybridisation and/or introgression between the ancestor of the modern forms of $P$. patens s.str. and $P$. vernalis may have occurred a long time ago during speciation.

According to our phylogenetic results, all the populations from different locations studied (except for population VI) belong to the same species. Even though ITS2, matK and $r b c \mathrm{~L}$ were found to be suitable regions for barcoding in species of Pulsatilla, in our study, they did not allow us to isolate P. uralensis from monochrome populations in north-eastern European Russia and the Urals into a separate group. The absence of divergence in the tree (see Fig. 4) may indicate the hybrid origin of all yellow-flowered samples and the hybrid origin of modern $P$. uralensis populations. Our results indicate recent speciation and incomplete lineage sorting, resulting in very few accumulated genetic differences. This study suggests that $P$. uralensis should not be recognised as a separate species, despite its Ural-Siberian detached range, yellow flowers, and finer leaf lobes. Despite being morphologically identified by the colour of its perianth and leaf structure, our phylogenetic results do not support this distinction. Using the ITS2, matK and rbcL markers, we found only limited phylogenetic resolution within the P. subgenus Pulsatilla. Molecular data showed that the yellow-flowered taxon should be considered a subspecies within the $P$. patens s.lat. complex. At least in north-eastern European Russia and in the Urals, where its west distribution border passes, this taxon does not separate clearly from $P$. patens s.str. It is possible that the standard DNA barcode markers, ITS2, matK and $r b c \mathrm{~L}$, are not applicable within the $P$. patens complex and do not allow us to assess the divergence between these closely-related taxa.

Given the high morphological variability of $P$. patens s.lat. and the widespread presence of hybridogenic populations in the Urals in the Orenburg and Sverdlovsk Oblasts (Kulikov 2005, Sushentsov 2008) and the vicinity of the Komi Republic on the Russian Plain (Egorova et al. 2017), we can expect that many plants in the zone of overlapping of their ranges are hybrids. The morphological analysis also supports the opinion that P. uralensis is polymorphic with high variability of leaf characteristics (Sushentsov 2008). In order to clarify the species' limits of $P$. uralensis, a more detailed study with different methodological approaches is required, involving data on closely-related taxa from a wider area from Siberia and other parts of their range. This is beyond the scope of this study.

An indication of hybrid processes in Pulsatilla populations is their polychromy (Bobrov 1944). In greenhouse experiments, the hybrid progeny of $P$. patens s.lat. most 
often has yellow, sometimes white and blue and rarely pink perianth (at a ratio of 4:2:1) (Pavlova 1990). Taking into account the prevalence of polychrome and monochrome yellow-flowered populations of Pulsatilla in the Komi Republic, we believe that an intricate complex with a significant participation of hybrid forms has formed in this territory, whereas the populations of $P$. patens s.str. have limited distribution (e.g. population VI). It is possible that there is an active process of introgression and "supplanting" of the European blue-flowered P. patens s.str., followed by the "absorption" of this species by the Ural-Siberian yellow-flowered P. uralensis.

The obtained data are consistent with the results of the study of the population variability of morphological features of Pulsatilla in the adjacent territory (Sushentsov 2008; Egorova et al. 2017). To the south, in the basin of the Vyatka River $\left(57-58^{\circ} \mathrm{N}\right)$, we identified populations of $P$. patens s.str., as well as hybridogenous populations of P. patens s.str. $\times$ uralensis (Egorova et al. 2017). They occupy a different ecological niche, which is preserved within the territory of the Komi Republic. Yellow-flowered populations are common on the pine terraces in lichen pine forests. Such conditions (sandy biotopes favourable for cross-pollination and seed renewal with reduced competition from other plants) contribute to the manifestation of Pulsatilla polymorphism in hybridizsation zones. In the large monochrome yellow-flowered population No. $\mathrm{V}$ of $P$. uralensis in the pine forests of lichen type in the south of the republic, we found specimens with highly dissected leaves (samples No. 13, 14 and 21) that were also included in the clade of phylogenetic trees, together with the hybrid forms and $P$. patens s.str. Leaf-blade lobes of $P$. uralensis are finely dissected and the ultimate lobes (up to 43 pieces) are linear-lanceolate to narrowly linear, the central leaflet has an $8-12 \mathrm{~mm}$ petiolule.

Thus, using the sequences of chloroplast (matK, $r b c \mathrm{~L})$ and nuclear DNA (ITS2), we showed that, in north-eastern European Russia and the Urals, populations with yellow and blue-violet flowers belong to the same species (P. patens s.lat.). Isolated monochrome populations of $P$. patens s.str. with blue-violet flowers are preserved within the territory of the Komi Republic and have a limited distribution range.

Since there are still many questions about the taxonomy of $P$. patens s.lat. complex, we believe that, in order to improve the ability to distinguish closely-related taxa in this group, it is necessary1) to analsze a large number of plants with an accurate identification of the main diagnostic characteristics; to scrutinise additional morphological and micro-morphological characteristics; 2) to obtain information on the location of the studied samples in the species range (the centre or the border of the range); to obtain information on their possible hybridisation and introgression with other species of the genus Pulsatilla on this territory, taking into account the factor of overlapping and the relict nature of the communities; 3) to obtain information on the abundance, distribution range and genetic structure of populations. The use of DNA barcoding process, geographically-expanded sampling and analysis of the genetic structure of populations of closely related Pulsatilla species are necessary to reconstruct the phylogenetic relationships between taxa of series Patentes. 


\section{Acknowledgements}

The work was performed within the scope of the state task "Diversity of vegetation at the west macroslope of the Subpolar Ural» (no AAAA-A19-119011790022-1) and within the scope of the state task of Institute Botanic Garden of Ural Branch of the Russian Academy of Sciences (Ekaterinburg, Russia). The authors would like to thank the staff of the Institute of Biology (Syktyvkar, Russia) A.N. Smirnova, I.N. Sterlyagova and V.V. Startsev for help in collecting field material and also two anonymous reviewers for their comments on this manuscript.

\section{References}

Akeroyd JR (1993) Pulsatilla Miller. In: Mill RR (Ed.) Flora Europaea 1: 264-266 Andreicheva LG (2002) Pleistocene of the European Northeast [Плейстоцен европейского северо-востока]. Ekaterinburg, 321 pp. [In Russian]

Bakin OV (2005) Aboutthegenus Pulsatilla Mill. (Ranunculaceae) in the flora of Tatarstan. Works of the Volga-Kama State Nature Reserve 6: 193-198. [In Russian: О роде Pulsatilla Mill. (Ranunculaceae) во флоре Татарстана] [In Russian]

Bardunov NV, Novikov VS [Eds] (2008) The Red Data Book of the Russian Federation Moscow [In Russian]

Bobrov EG (1944) About the features of the flora of erratic region. Sovetskaja Botanika 2: 3-20. [In Russian]

BOLD Systems (2020) Published on the Internet http://www.boldsystems.org/ [accessed 10 January 2020]

Cai Y, Li S, Chen M, Jiang M-F, Liu Y, Xie Y-F, Sun Q, Jiang H-Z, Yin N-W, Wang L, Zhang R, Huang C-L, Lei K (2010) Molecular phylogeny of Ranunculaceae based on $r b c \mathrm{~L}$ sequences. Biologia 65: 997-1003. https://doi.org/10.2478/s11756-010-0105-8

Council of the European Union (2007) Council Directive 92/43/EEC of 21 May 1992 on the conservation of natural habitats and of wild fauna and flora, version 1.1.2007. http:// ec.europa.eu/environment/nature/legislation/habitatsdirective/index_en.htm

Council of the European Union (2007) Council Directive 92/43/EEC of 21 May 1992 on the conservation of natural habitats and of wild fauna and flora, version 1.1.2007. http:// ec.europa.eu/environment/nature/legislation/habitatsdirective/index_en.htm

Egorova NY, Egoshina TL, Sushentsov OE (2017) Population variability of Pulsatilla patens s.l. (Ranunculaceae) in the Vyatka river basin. Rastitel'nye Resursy 53(2): 237-254. [In Russian] Grey-Wilson C (2014) Pasque-flowers. The genus Pulsatilla. The Charlotte Louise Press, Kenning hall.

Holub J, Prochazka F (2000) Red list of vascular plants of the Czech Republic - 2000. Preslia 72: $187-230$.

Hoot SB, Reznicek AA, Palmer JD (1994) Phylogenetic relationship in Anemone (Ranunculaceae) based on morphology and chloroplast DNA. Systematic Botany 19(1): 169-200. https://doi.org/10.2307/2419720 
Hoot SB, Meyer KM, Manning JC (2012) Phylogeny and reclassification of Anemone (Ranunculaceae), with an emphasis on Austral species. Systematic Botany 37(1): 139-152. https:// doi.org/10.1600/036364412X616729

Ilchukov SV (2010) Landscapes of the Republic of Komi. Ekaterinburg, 198 pp. [In Russian] Juzepczuk SV (1937) Pulsatilla Adans. In: Komarov VL, Schischkin BK (Eds) Flora of the USSR. Volume 7. Editio Academiae Scientiarum URSS, Moscow, Leningrad, 285-307. [In Russian]

Knyazev MS, Mamaev SA, Vlasenko VE (2007) Relict communities and populations of petrophilous plant species in northern regions of Sverdlovsk Oblast and problems in their conservation. Russian Journal of Ecology 38(5): 317-322. https://doi.org/10.1134/ S1067413607050049

Kress WJ, Erickson DL, Jones FA, Swenson NG, Perez R, Sanjur O, Bermingham E (2009) Plant DNA barcodes and a community phylogeny of a tropical forest dynamics plot in Panama. Proceedings of the National Academy of Sciences of the United States of America 106(44): 18621-18626. https://doi.org/10.1073/pnas.0909820106

Kricsfalusy VV (2015) Taxonomy and phylogeny of Anemone patens L. sensu lato (Ranunculaceae): A critical review Thaiszia. Le Journal de Botanique 25: 153-164.

Kulikov PV (2005) Synopsis of the flora of the Chelyabinsk region (vascular plants). [In Russian: Конспект флоры Челябинской области (сосудистые растения)]. Ekaterinburg, Miass, 537 pp. [In Russian]

Kulikov PV, Zolotareva NV, Podgayevskaya EN (2013) Endemic plants of the Urals in the flora of the Sverdlovsk region. [In Russian: Эндемичные растения Урала во флоре Свердловской области]. Ekaterinburg, 612 pp. [In Russian]

Kumar S, Stecher G, Li M, Knyaz C, Tamura K (2018) MEGA X: Molecular Evolutionary Genetics Analysis across computing platforms. Molecular Biology and Evolution. 35(1): 1547-1549. https://doi.org/10.1093/molbev/msy096

Li Q, Wang X, Wang J, Su N, Zhang L, Ma Y, Chang Z-y, Zhao L, Potter D (2019) Efficient Identification of Pulsatilla (Ranunculaceae) using DNA barcodes and micromorphological characters. Frontiers of Plant Science 10: 1196. https://doi.org/10.3389/ fpls.2019.01196

Malyshev LI (2012) Ranunculaceae. In: Baikov KS (Ed.) Conspectus Florae Rossiae Asiaticae: Plantae Vasculares [In Russian: Конспект флоры Азиатской России: сосудистые растения]. Publishing House of the Siberian Branch of the Russian Academy of Sciences, Novosibirsk, 31-55. [In Russian]

Martynenko VA (2009) Pulsatilla patens (L.) Mill. The Red Data Book of the Komi Republic, Syktyvkar, 515 pp. [In Russian]

NCBI (2020) National Center for Biotechnology Information. Published on the Internet. https://www.ncbi.nlm.nih.gov/ [accessed $5^{\text {th }}$ February 2020]

Pavlova TA (1990) Pulsatilla patens (L.) Mill. in nature and culture. Novosibirsk, 79 pp. [In Russian]

Ronikier M, Costa A, Aguilar JF, Feliner GN, Küpfer P, Mirek Z (2008) Phylogeography of Pulsatilla vernalis (L.) Mill. (Ranunculaceae): Chloroplast DNA reveals two evolutionary lineages across central Europe and Scandinavia. Journal of Biogeography 35(9): 16501664. https://doi.org/10.1111/j.1365-2699.2008.01907.x 
Ronquist F, Huelsenbeck JP (2003) MrBayes 3: Bayesian phylogenetic inference under mixed models. Bioinformatics (Oxford, England) 19(12): 1572-1574. https://doi.org/10.1093/ bioinformatics/btg 180

Saddhe AA, Kumar K (2017) DNA barcoding of plants: Selection of core markers for taxonomic groups. Plant Science Today 5(1): 9-13. https://doi.org/10.14719/pst.2018.5.1.356

Somlay L (2000) A Pulsatilla flavescens (Hazsl.) Borb. emend. Borosprioritasanakvedelmeben. Kitaibelia 5: 245-248.

Sramko G, Laczko L, Volkova PA, Bateman RM, Mlinarec J (2019) Evolutionary history of the Pasque-flowers (Pulsatilla, Ranunculaceae): Molecular phylogenetics, systematics and rDNA evolution. Molecular Phylogenetics and Evolution 135: 45-61. https://doi. org/10.1016/j.ympev.2019.02.015

Stepanov NV (2014) Notes about some species of Pulsatilla L. (Ranunculaceae) from the NearYenisey Sayans Mountains [In Russian: Заметки о некоторых видах Pulsatilla L. (Ranunculaceae) из приенисейских Саян]. Systematic notes on the materials of P.N. Krylov Herbarium of Tomsk State University 109: 6-19. [In Russian]

Sushentsov OE (2008) Systematic composition, chorology and structure of populations of species of the genus Pulsatilla Mill. (Ranunculaceae Juss.) in the Ural region [In Russian: Систематический состав, хорология и структура популяций видов рода Pulsatilla Mill. (Ranunculaceae Juss.) в Уральском регионе]. PhD Thesis, Botanical Garden of Ural Branch of Russian Academy of Sciences, Yekaterinburg, 107 pp. [In Russian]

Tamura M (1995) Phylogeny and classification of the Ranunculaceae. Plant Systematics and Evolution. Supplementum 9: 223-519. https://link.springer.com/chapter/10.1007/978-3-7091-6612-3_20

Teteryuk LV, Zheleznova GV, Kanev VA, et al. (2006) The biological diversity of the specially protected natural territories of the Komi Republic. Vol. 4. Protected natural complexes of Timan [In Russian: Биологическое разнообразие особо охраняемых природных территорий Республики Коми. Вып. 4. Охраняемые природные комплексы Тимана]. Syktyvkar, 272 pp. [In Russian]

The Euro+Med PlantBase (2020) Published on the Internet. http://www.emplantbase.org [accessed 5 February 2020]

The IUCN Red List of Threatened Species (2019) Version 2019. http:/www.iucnredlist.org

The Plant List (2020) Version 1.1. Published on the Internet. http://www.theplantlist.org/ [accessed $10^{\text {th }}$ January 2020]

Thompson JD, Higgins DG, Gibson TJ (1994) CLUSTALW: Improving the sensitivity of progressive multiple sequence alignment through sequence weighting, position-specific gap penalties and weight matrix choice. Nucleic Acids Research 22(22): 4673-4680. https:// doi.org/10.1093/nar/22.22.4673

Timokhina SA (1993) Pulsatilla Miller. In: Malysheva LI, Peshkova GA (Eds) Flora of Siberia, Novosibirsk, 149-155. [In Russian]

Tzvelev NN (2001) The genus Pulsatilla Mill. In: Tzvelev NN (Ed.) Flora of Eastern Europe. Saint Petersburg, 85-94. [In Russian]

Tzvelev NN (2012) Pulsatilla. In: Tzvelev NN, Geltman DV (Eds) Conspectus Florae Europae Orientalis, Volume 1. KMK Scientific Press, Moscow \& St. Petersburg, 114-117. [In Russian] 
Wattoo JI, Saleem MZ, Shahzad MS, et al. (2016) DNA Barcoding: Amplification and sequence analysis of $r b c L$ and mat $K$ genome regions in three divergent plant species. Adv Life Sci 4:03-07 http://www.als-journal.com/articles/vol4issue1/412.16/298.pdf

World Flora Online (2020) Published on the Internet. http://www.worldfloraonline.org/ [accessed 5 February 2020]

Yudin YP (1963) Relict limestone flora of the North Eastern European part of the USSR. Materials on history of flora and vegetation of the USSR. Moscow, 493-587. [In Russian]

\section{Supplementary material I}

\section{Maximum Likelihood and Bayesian Inference phylogenetic tree (rbcL)}

Authors: Olga E. Valuyskikh, Ludmila V. Teteryuk, Yana I. Pylina1, Oleg E. Sushentsov, Nikita A. Martynenko, Dmitry M. Shadrin

Data type: phylogenetic tree

Explanation note: Maximum Likelihood and Bayesian Inference phylogenetic tree $(r b c \mathrm{~L})$ of 13 sequences of $P$. patens s.str. and 16 sequences of $P$. uralensis, plus the nine selected sequences in GenBank and BOLD Systems for different Pulsatilla species. Posterior probability and bootstraps are shown at the nodes, values below $50 \%$ are not shown.

Copyright notice: This dataset is made available under the Open Database License (http://opendatacommons.org/licenses/odbl/1.0/). The Open Database License $(\mathrm{ODbL})$ is a license agreement intended to allow users to freely share, modify, and use this Dataset while maintaining this same freedom for others, provided that the original source and author(s) are credited.

Link: https://doi.org/10.3897/phytokeys.162.53361.suppl1

\section{Supplementary material 2}

\section{Informative nucleotide sites in cpDNA (matK, rbcL) for Pulsatilla}

Authors: Olga E. Valuyskikh, Ludmila V. Teteryuk, Yana I. Pylina1, Oleg E. Sushentsov, Nikita A. Martynenko, Dmitry M. Shadrin

Data type: molecular data

Copyright notice: This dataset is made available under the Open Database License (http://opendatacommons.org/licenses/odbl/1.0/). The Open Database License $(\mathrm{ODbL})$ is a license agreement intended to allow users to freely share, modify, and use this Dataset while maintaining this same freedom for others, provided that the original source and author(s) are credited.

Link: https://doi.org/10.3897/phytokeys.162.53361.suppl2 


\section{Supplementary material 3}

Maximum Likelihood and Bayesian Inference phylogenetic tree (matK) of 13 sequences of $P$. patens s.str. and 16 sequences of $P$. uralensis

Authors: Olga E. Valuyskikh, Ludmila V. Teteryuk, Yana I. Pylina1, Oleg E. Sushentsov, Nikita A. Martynenko, Dmitry M. Shadrin

Data type: phylogenetic tree

Explanation note: Maximum Likelihood and Bayesian Inference phylogenetic tree (mat $\mathrm{K}$ ) of 13 sequences of $P$. patens s.str. and 16 sequences of $P$. uralensis, plus the nine selected sequences in GenBank and BOLD Systems for different species. Bootstraps and posterior probabilities are shown at the nodes, values below 50\% are not shown.

Copyright notice: This dataset is made available under the Open Database License (http://opendatacommons.org/licenses/odbl/1.0/). The Open Database License $(\mathrm{ODbL})$ is a license agreement intended to allow users to freely share, modify, and use this Dataset while maintaining this same freedom for others, provided that the original source and author(s) are credited.

Link: https://doi.org/10.3897/phytokeys.162.53361.suppl3

\section{Supplementary material 4}

Phylogenetic tree (ITS2) constructed using the Maximum Likelihood and Bayesian Inference of the 13 sequences of $P$. patens s.str. and 15 sequences of $P$. uralensis Authors: Olga E. Valuyskikh, Ludmila V. Teteryuk, Yana I. Pylina1, Oleg E. Sushentsov, Nikita A. Martynenko, Dmitry M. Shadrin

Data type: phylogenetic tree

Explanation note: Phylogenetic tree (ITS2) constructed using the Maximum Likelihood and Bayesian Inference of the 13 sequences of P. patens s.str. and 15 sequences of $P$. uralensis, plus the nine selected sequences in GenBank and BOLD Systems for different species. Bootstraps and posterior probabilities are shown at the nodes, values below $50 \%$ are not shown.

Copyright notice: This dataset is made available under the Open Database License (http://opendatacommons.org/licenses/odbl/1.0/). The Open Database License $(\mathrm{ODbL})$ is a license agreement intended to allow users to freely share, modify, and use this Dataset while maintaining this same freedom for others, provided that the original source and author(s) are credited.

Link: https://doi.org/10.3897/phytokeys.162.53361.suppl4 